\title{
Traditional Referentiality in Felix Khensay's Literary Contribution
}

\author{
Jonnelle D. Fagsao \\ Teacher Education Department \\ Bontoc, Mountain Province, CAR, Philippines
}

\begin{abstract}
This paper borrows the concept of traditional referentiality from Oral Traditional Theory and applies it to interpret the songs of Felix Khensayof Bontoc, Mountain Province, Philippines adapted by contemporary pop music enthusiasts as performed by a Bontok band called the Petune and other national choral groups with special kind of improvisation and fusion. It also informs briefly who Felix Khensay as a distinctive Bontokcomposer, his songs written in a Bontok language, his melodic and poetic styles, and patterns, and also the evocative application of his songs that became referentially meaningful in the memories of the Bontok community. The paper then installs traditional referentiality(TR) as a concept framed from the lens of Oral Tradition Theory and anchored on Michael Drout's Meme Based Approach and applies it to the common songs produced by the Petune band and also as a winning piece of a national choral competition in the Philippines. It also explains and illuminates the operations of anaphoric repetition and pattern-recognition on the musical texts of Khensay's selected two songs. Through textual analysis, this paper contributes making an initial assessment of Khensay's songs' functions viewed as cultural universals in the traditional referents that are significant to the Bontok community.
\end{abstract}

Keywords: anaphora, Bontoc, Mountain Province, Bontok, Felix Khensay, Folk literature, meme-based approach, traditional referentiality

\section{INTRODUCTION}

Felix Khensay's Music. Music is found in every part of the world. It is a universal human activity. No one knows how much music there is, but the amount must be tremendous. The form and styles of the music people are as varied as their language and ways of life. Folk music is a fascinating and significant area of the world of music (Hopper 1985, 6).

It is in many ways, music is the most abstract of the arts. It cannot be itself without words, tell a story or ideas describe explicit situation. It operates on a more elemental level of expression. A composition has no single meaning because music is a non-figurative language where there is no direct concrete connotation. Its meaning occurs on several levels either obviously or weakly perceived. We may not even be intentionally conscious of some of the most noteworthy ways where music appeals to us (Schindler 1980, 2-3).

Music, according to Bakan $(2011,9)$, is a cultural issue where human life is: in the way what people do, think, believe, and value. When we explore them, we are exploring what is known in the social sciences as culture. Music is a cultural issue. Going through the diffusion of culture, a single individual constructs and generates an impression of a comprehensive music that is innate. In other words, one's concept of music is created and nurtured by his or her upbringing within a culture (Zelewicz 2006, 5). "Music," says Bakan "comes into existence at the intersection of sound and culture of which, it is not until some kind of meaning which is the essential glue that is connected to sounds heard as random and culture to form music" $(2011,11)$.

Allan P. Merriam (1964) mentions "that music exists only in terms of social interaction uniquely; that is, it is made by people for other people, and it is a learned human behaviour" (27). York (1995) and Seeger (1994) cited a Melanesian islander from the Torres Strait who argues that "Music also is of intrinsic importance in our lives. As such, it is a social issue. "The sound of music is the consequence of a multiple human social communicative processes that are fashioned by the standards, attitudes, and principles of the society who are involved on a specific culture" (Merriam 1964:6) Music is part of our social events, where we celebrate our culture together as quoted in Connel and Gibson(2001, 20). 
Every culture has its own songs which bear the way of life that produced them. Like other ethnic groups within the country, the Bontoks have their own music. Such music carries a significant part of their culture especially in central Bontoc, Mountain Province. I will now take this opportunity to confess my passion in Khensay's music. It grew out after I joined a choral group whose songs rendered are Khensay's compositions, which, incidentally, laid the ground work for the formal organization of the Mountain Province State Polytechnic College (MPSPC) Minstrels choir. My musical exposure to Khensay's songs inspired me to do a research of his compositions.

Among the great lyric writers of Bontok songs from 1940s to 1990s was Felix Khensay (1919-2004) who made a great impact on the life of the Bontoks worldwide. His lyrics are distinguished for their seriousness of feeling and thought expressed in simple, yet sophisticated language. His melody or music is made in specific geographical and cultural contexts, and his lyrics and styles are always likely to reflect his being an "Ifuntok" composer. The melodies he wrote were so memorable, that others found themselves singing along without even knowing or understanding some of his profound lyrics in the local language, but even then, Bontoks still enjoy the frequent ceremonial occasions in which Khensay's songs are performed.

Among the personal accounts of Khensay's song writing process is that of his eldest son Ignacio Khensay (2015) would recalled that "he would squat on the floor, hum a certain unique sound, and perched on his rocking wooden chair scribbling lyrical ideas on a piece of paper or even on walls of his room." (Interview by the author, Bontoc, Mountain Province, February 12, 2015).

To date, Khensay's songs are still being popularized through choral notations or rearrangements as musical texts for contests and concerts. Others like the bands Petune; a group of Bontok musicians noted for their improvised Khensay's songs with a degree of fixity of the tune in a contemporary reggae genre, and The Living Anitos(TLA) performed, improvised and recorded their song that "fuses ethnic and foreign instrumentation and melodic patterns, a hybridized music format which forms part of a larger, though disparate, trend among local performing groups in the Cordillera" (Saboy 2012,39). In ethnomusicology improvisation is considered to be "composition through performance" as mentioned by Zelewicks $(2006,8)$.

The Petune band and other local choral groups in Bontoc, Mountain Province and in other State Universities and Colleges in the Cordillera performed Khensay's songs with cultural interpretations and thematic understanding which are fixed in the musical texts predominantly on romantic (local marriage customs and conflicted lovers, youthful passion and unrequited love); cultural (pride in one's indigenous roots, personal choice and filial/communal duty); and religious (Divine Providence, moral sensitivity and community relations similar to Saboy's findings $(2012,39)$.

This paper is a study of traditional referentiality and memetics from Oral Theory and applies it on contemporary pop music as seen in the works of the Bontok poet and composer Felix Khensay of Bontoc, Mountain Province. It first introduces the composer, describes his compositional style and melodic patterns, and discusses the relevance of his music to the Bontok community.

\section{A. Felix Khensay}

The poet of the Bontok community. The lyrics written by Felix Khensay have subsidized extensively to the development of the Bontok community worldwide through the powerful messages of his songs which incorporate all aspects of human life. His passion for Bontok indigenous language and his excessive appreciation for feminine beauty made him pen some "khag-awis ay ayoweng pal aisnan am-in ya engengkhana" (wonderful masterpieces of all time) as mentioned by Julia Bete (February 18,2015 in an interview at their residence in Omfeg, Bontoc, Mountain Province). Poet Khensay wrote lyrics on many aspects of human life ranging from Bontok women and men, life in the Bontok "ili", Bontok society, culture, language, art of living in the valley of Bontok, art of dying, cycles of life, charity, love, education, and of course on human values and moral standards and many other topics of societal interest as mentioned by Elizabeth Tud-long Longid (April 8,2015) when asked about Khensay's songs during a family gathering in Loc-ong, Bontoc, Mountain Province. The lyrics composed by poet Khensay fascinated people from all walks of life encroaching into background, belief or social barriers.

Khensay's compositions which are full of romantic connotations of creativity were learned by the Bontok society which practices theBontok's social values by analysing the songs' text for what they express, and contributing to music change and stability. His songs were heard to identify and to explain something about the Bontok culture to others.

Felix Khensay was born and raised in Bontoc, Mountain Province. Raised totally in a rural environment particularly on the playgrounds of Bontoc Ili, he mentions this factor as background and setting for his children's stories and songs all written in the Bontok language. He spent twenty-five (25) years translating the English Bible into Bontok, language and had also been known as a literary critics, 
singer, community leader, short story writer, and song and chant composer. His compositions have offered sources of inspiration to a number of our local music enthusiasts likeDr. Benjamin Misa who tried to elevate Khensay's"Odem-dem" into choral setting and his effort won the NAMCYA composition award youth choir in 1982. His other songs were arranged into SATB choral arrangement by Father Daniel P. Carino of the Episcopal Diocese of Northern Philippines (EDNP), and Mrs. Sofia O. Bacwaden, a retired principal of All Saints Mission Elementary School in Bontoc, Mountain Province.

Khensay wrote lyrics on many aspects of human life ranging from Bontok women and men, life in the Bontok"ili"(village). Basing from what Merriam's category of composers, he is "a specialist composer, a man who may or may not gain payment in return from his activities but who is socially recognized as performing a specialized function in composing songs" $(1964,184)$.For, after all is said and done, it is not the singer but the composer who is remembered by posterity.

The Bontoks today study their literature not in terms of its uses in the past but in terms of its functions in the present. In the case of Khensay's songs, he (Khensay) has a unique melody and sound structure and concentrated on lyrics that depict Bontok's culture. Although contemporary musicians in the community adapted tunes and translated western lyrics into the Bontok language, Khensay impressed the locals with his original melodies and lyrics.

Khensay's collections were prepared to provide a literature with which to build reading skills in the vernacular for the Bontok people and also to serve as a bridge for the transition from the mother tongue to the English as a second language. Before Khensay's composed songsvanished and are totally forgotten, it is indeed timely to gather them, from a few living sources in Bontoc, Mountain Province.

With this clamour on the search for Felix Khensay's songs, these have become a valid area for educational research in order to determine the richness of his songs as effective educational resources. Since folk literature validates culture, there is a need to preserve materials necessary to become means of appreciating the culture which it reflects.

I concentrated on the significance of the songs of FelixKhensay's to the Bontok society, particular on the collection, transcription, and translation of his popular works withthemes that are framed on the Bontok culture; the spiritual and social obligations; and romance.

It is also imperative that since Bontoc, Mountain Province has become a regional mélange in the hinterlands, the people who inhabit the place need to read, study, understand and appreciate Khensay'ssongs as a means of knowing who Felix Khensay is to the Bontok people and as a means of understanding the Bontoks as a people: their hopes, their dreams, their aspirations and their beliefs as reflected in his songs.

These songs were gathered from researches and interviews focusing primarily on their musical texts transcriptions and the songs' cultural context. I believe that the end goal should be to incorporate issues of both ethnography and musical transcription in this study.

B. Drout's Meme-Based Approach to Oral Traditional Theory

Many of the theoretical concepts of ethnomusicology are important because they define the direction of one's research. This paper explores some selected songs of Felix Khensay framed from the lens of Oral Tradition Theory particularly on the concept of Michael Drout's Meme Based Approach that focuses on traditional referentiality.

When one imitates someone else, something is passed on again and again taking a life of its own. We might call this thing, knowledge, lessons, manners, a piece of factual data, cultural songs...but then in this study, I shall need to give it a name -- 'meme'.

Drout (2006: 269) defines meme as the meekest element of cultural duplication; it is whatsoever is spread when one person duplicates, consciously or unconsciously, another an element of a culture that may be painstaking considered to be handed on by non-genetic means, esp. imitation (Blackmore 1999. viii) and information patterns infecting human minds (Grant 1990). Meme theory can explicate the works of numerous recognized and much conversed features of oral traditions. Drout notes that when one person imitates performance of another; a meme has accomplished to reproduce itself by being copied from one human mind to another. Once a meme has been deposited in a person's memory, and if that meme is part of some kind of repeated pattern, it can be called back into conscious insight by some smaller critical portion of the meme.

C. Traditional Referentiality

John Miles Foley as cited by Saboy (2012) defines traditional referentiality (TR) as "the resonance between the singular moment and the traditional context". In an earlier work, he explains that it "involves 
the appealing of the context that is enormously larger and more echoic than the text or work itself that brings the essence of poetic presentations to the individual performance or text." To credit Saboy's concept of Traditional Referentiality, he points out that:

The concept was originally formulated from a reading of Homeric epics whose traditional referents, Foley observes, comprise the central expressive strategy. He adds that when read in a particular discourse, these bytes of phraseology and narrative pattern serve to index traditional ideas, characters, and situations, standing by prior negotiation for much more than a literary reading alone can decode. Under this concept, linguistic "index markers," i.e., terms, expressions, and other linguistic patterns implicate the socio-cultural, milieu in which these were first located. (40).

Basing from Saboy (2012.40), he points out that Michael Drout (2006) combined the application of the concept to his Meme-Based Approach which he refers as "the triggering or cuing meme" and melds it with Foley's traditional referent (TR) or index marker (IM). Furthermore, Blackmore (1999. 6) termed it as "mimeme", a term that conveys the idea of a unit of cultural transmission, or a unit of imitation.

D. Selected Songs of Felix Khensay

Let me present the selected songs of Khensay which are entangled with "music as culture" (Bakan 2012 , 10). With this considerable focus on the cultural context of Kensay's songs, let me express my opinion concerning Robert Garfias' $(2012,7)$ quotation that:

Music is a product of a culture and is a very significant process for expressing personal and group manifestations on history, politics, economics as well as aesthetics which has played upon it.

Magmagkit ay Tet-Ewa (A Lady True)

Words and Music by Felix Khensay/ Translated by Sofia Oakes Bacwaden and Estella O. Felwa

Magmagkitka'ytetewa That she is a lady true Fafa-i ad-inalaka

She is virtuous through and through

Sakangemya en cheg yang

Ilaemkaglumalanglang ay ay

Look at her and you'll admire

Ngem ad-inaiwa-yang

A beauty rare beyond compare ay ay

Ni lagwey nay pinpin-nang

She guards well her purity

Gifts of love not given free

Layche nan es-esang

Adika fas afasang ay ay

Odemdem (Words and Music by Felix Khensay)

Odem-dem

She will love just only one

She does not fleet from man to man, ay

Ma-id kasinteken

Si eklaychen,

whom I adore

Odem-dem

There is no one else

ismangepan

$5 \quad$ Nan eknem-nem

and admire

Mo di sik-a

Ay eksem-sem ken

Lay-lay chek ay dalen.

La, li, lay si Dong-ilay

I always think of you

no one but you

whom I thinking of

My darling dear

The song Magmagkit Ay Tit-iwa (MAT) is all about Khensay's descriptions of a "magmagkit" (Bontok maiden) as "true", "virtuous", and "pure". She possesses a quality of being beautiful, industrious, sweet, kind, and soft and smooth and is metaphorically compared to a red chiselled pinewood and a bird with a beauty paralleled to the daylight. She can be considered either as a woman, or a role model among the women of the entire Bontok "tribe".

The second song, "Odemdem" is a dramatic love song expressed by a Bontok "fab-alo" (young bachelor) to a young "mag-magkit" (maiden) which he mentions in the song as "dalen" to which highlights the ardent affection and true sincere feelings of his character and the normality which surrounds his emotions to an unnamed maiden.

Fagsao (2015.107) expressed in his study on Bontok contemporary songs that "passion in music has been normally conveyed in all cultures regardless of gender, race, and age groups. Important indications of cultural development were based on cultural love songs." Kalof $(1993)$ as cited by Fagsao $(2015,210)$ reasoned that many of Khensay songs is so powerful that it ultimately defines sexual imagery particularly on femininity as expressed in lines 21-22 in MAT and macho imagery as manifested in line1 of the song "Odemdem." 
Khensay's songs express some of components and qualities about love that includes intimacy, passion and commitment. The message of love in the song expresses an investment of attention of another person (the speaker) with his intention of realizing his ultimate goals to another person as Peck (1978) called this aspect of love circularity. Furthermore, Peck argued that it is but normal that one develops emotionally through loving, and one must love oneself to be capable of loving another.

\section{E. Khensay's Poetic Style}

1) Anaphoric Repetition. Anaphoric repetition is referred to as the repetition of a word or a phrase at the beginning of two or more successive sentences applied often in poetry that intensifies the sounding coordination of speech (Kemertelidze 2013: 4).

As a poetic figure, anaphora is used to describe the repetition of elements at the beginning of a poetic unit where repeated actions begins and ends in every stanza (Drout 2006, 283). Drout (2006:286) also ties anaphora and traditional referentiality to help generate stylistic inertia because the imitation of style is a way for memes to increase the likelihood that they will be duplicated and handed from the minds of every generation. In circumstance, one distinctive characteristic of oral traditions is their stylistic traditionalism: this is the most recognized way in traditions. Anaphoric repetition is met not only in emotive prose but it is rather used in Khensay songs.

Drout (2006:286) also ties anaphora and traditional referentiality to help generate stylistic inertia because the imitation of style is a way for memes to increase the likelihood that they will be duplicated and passed from a person's mind to another. In fact, one characteristic of traditions, particularly oral traditions, is their musical conservatism: this is one of the ways we distinguish traditions. Anaphoric repetition is met not only in emotive prose but it is rather used in Khensay songs.

Focused on the operations of anaphoric repetition and pattern-recognition he used on the musical texts of the songs, here are songs some of the songs where he used the anaphoric repetition "ChayawenTako ay Enkanta" (Let's Sing and Praise Him) and "Nay Chawatem ay Apo" (Here, Accept This, O Lord). These songs are very much evident and widely used in any types of musical genre approved formally and informally by the people who are to perform it.

"Nay Chawatem ay Apo"

Here, Accept This, O Lord

Words and Music by Felix Khensay and Daniel P. Carino

Nay chawatem ay Apo

Layad mi ay lihkalo

Accept our offering, O Lord

Alaem nan micho-o

And as we offer ourselves

Elot ay mo id tongcho

5 Awak na ya chala na, Ay

Bless our thoughts and de

Anak mo ay Chios Ama

That we may have strength to serve you

Wed-wecha'y icho-o mi

His own body and blood

Ken sika'y Apo Chios mi

Your son, O Lord

As we offer our lives

To you o Lord

"ChayawenTako ay Enkanta" Let's Sing and Praise Him

Words and Music by Felix Khensay and Rev. Daniel P. Carino

Chayaw Ken Chios Ama (4x)

Chayawen tako ay en kanta (3x)

Si Apo ay Chios Ama

3 Machad ayaw nan ngacha na (3x)

Si Apo ay Chios Ama
Let's sing and praise $\operatorname{Him}(4 \mathrm{x})$

Let's sing and praise $(3 \mathrm{x})$

Our Lord

May His name be praised $(3 \mathrm{x})$

There are religious memes that are used by Khensay in these songs that include the idea of an supreme and all-knowing God which is referred also to "Lumawig" who is able to hear and answers their "kapya"(prayers). Since Khensay is considered also a translator of the Bible (from English to Bontok), he adapted his lyrics from the biblical texts and describing itself as essential and necessary to the people who read and sing it. It is particularly flexible and much of its content can be used to substantiate moral bearing.

If we look at these songs from a point of view of replication, we can comprehend why they have been so popular to the Bontoks. The memes in Khensay's songs did not set out with a purpose to prosper but they are just Biblical thoughts and stories that were copied to fully give thoughtful understanding of religion in a 
mother tongue view. They evoked strong emotions and repeatedly passed on to more and used the beauty of its memetic tune to help their spread. That is why they are still in every "Ifuntok's" repertoire of songs.

In the study of Drout (2006), Foley has discussed the way traditions construct the consequence of "anaphora" (1991a:9-10) by mentioning it as a term used to describe the repetition of elements at the beginning of a poetic unit.

For example in the songs "Magmagkit" and "Odem-dem", both contain anaphoric elements which are repeated constructions found in the first and the last lines of each songs. These repeated constructions serve to link together the parts of each poetic unit as well as the repeated elements.

Some of the Khensay's songs begins and ends with repeated actions. Encountering the repeated initial element, the reader who participates in the tradition is able to infer the rest of the unit via the metonymic process of traditional referentiality (Foley 1995:13). The existence of anaphoric elements of the songs thus causes readers not only to fill in the gaps in the current text with the traditional elements invoked by traditional referentiality, but also to estimate the shape of portions of the songs that they have not yet encountered. Anaphora and traditional referentiality, then, help to generate stylistic inertia because the imitation of style is a way for memes to increase the likelihood that they will be replicated and passed from mind to mind.

The songs of Khensay proceeds mostly in a repeated tones and lyrics, changing from one centre of tones to another, with melodic styles linking one set of tone to another. Characters of personages in the love songs of Khensay are described by a rise and fall melodic repetitions. Like in Kalinga's"ulallim" studied by Saboy (2012), begins with an opening line "Kanankanudin'ullalimee..." (So says the ullalim), announcing the story in a characteristic melodic phrase, which is followed by the narration sung mostly in monotone.

2) Traditional Referents.The process of traditional referentiality entails the pragmatic process of contextualization, but because it applies specifically to oral-derived texts, I employ the oral traditional theory here.

Everything that is passed to every audience like the songs composed by Khensay is a meme which evolved in its own unique way. The audience is exposed to the text underlying the oral performance and thereby to the referential processes it habitually employs. Indeed, every time these songs are being sung, Khensay's tune affects every "Ifuntoks" and stirs up the memory they have already possess. And where did it come from? It is acquired through imitation. Something, some kind of information, some kind of instruction, has become lodged in all their brains even when humming these songs at any occasions. This is what we call the meme.

From the selected songs of Khensay, like the "Odemdem", and "Magmagkit ay Tet-ewa", traditional referents can be identified. These traditional referents may spread because of the expression embedded in the songs, a phrasal description about a traditional Bontok woman, chord patterns, rhythmic changes, or alterations in instrumentation as well as the memetic tunes and melodic style used by Khensay.

3) "Odemdem": In the song, "Odemdem", it is worth noting that the composer uses "dalen" in his last lines instead of the usual word "darling" to express the idea of romance to the way the Ifuntoks pronounce it. The speaker truly flatters the maiden in the song who had spent his whole life slaving "nan ek-fa-a" over the maiden to love and adore him in return "lay-lay- chek ay dalen". He beseeched the maiden to have pity "sumeg-ang"(line 11) on him, and goes on to insist her to perceive or envision him, to perceive how he truly loves her, as he has always been present for no one dares to love and adore her except him, the reason behind his lively expression. He continues on persuading the maiden. Finding the fact that things so simple and worthy could make him as happy as perhaps her gift to him if she accepts his true love from him. He goes on to say that in lines 2-3 (I will truly love you and nobody else except me - ma-id kasinteken/ sieklaychen/ modisik-a). He hints at the fact that the "dalen" he describes, seemed to smile at him in the same way that he smiled at him, which is implied from the expression "didiyao-didiyao-diyao"(line 18) -seems to be a superlative expression of jubilation from the speaker.He again directs the attention of his affection to the "dalen" maiden towards the resolution of the song and repeats himself from earlier saying that "ma-id kasintekkensienaklaychenmodisik-a" (Nobody else except you whom I will love and adore) (lines 2-3).

4) "Magmagkit": Prill-Brett (2015) mentions that feminist anthropologists have observed from crosscultural perspectives that to understand gender relations is to analyse these in the context of time periods, social class, ethnicity, education, ideology, age, degree of acculturation, and other experiences as these intersect in women's lives (191-192).The domain where femininity is expressed by a woman is 
narrow and limited to a certain point, because it is limited to her life where her feminine role is mainly revealed where she can show her feminine traits through being industrious as the composer in the song mentioned. Thus, her role of being an industrious woman, which is valued in the Bontok society, remains her most essential roles in the Bontok life ways as a reminder among the young maidens of Bontoc. "Magmagkit" is established in Khensay's song, that in a woman's actions, she is a person of purpose and a motive; person of will and determination; person of warmth and care; and person who have a task to carry out proving that she has the capability to take part in every Bontok life.

Phrasal descriptions of the "magmagkit's" persona in the song can remind the Bontok people about how a true "magmagkit" can be represented as where memetics begin. This is cultural information describing the Bontok maiden that is copied from person to person with difference and variety.

"Dongdong-ay": This is similar to "salidummay" which according to Saboy (2012: 55) is a "memetic, multimelodic oral tradition that has been appropriated by different ethnic groups across the country for every imaginable use from children's rhymes and campfire ditties to political jingles and commercial advertisements."

In the two songs above, Khensay weaves a compelling tale of love, affection and warmth which in equal parts delights the reader. One is appalled at the performance of the speaker, and is amazed at the beauty and majesty of the language used as a vast complex of interconnected and co-evolved memes, which is truly a Khensay style as one would enjoy immensely as it was a thrilling yarn which had everyone captivated throughout including me.

\section{CONCLUSION}

There is noteworthy suggestion to show that the songs of Khensay function widely as a means of passionate and adoring manifestation. In discussing the two love song's texts, it was pointed out that one of their outstanding features is the fact that they offer transportation of ideas and emotions not exposed in a common place of discourse. It seems to me that Khensay composed his songs also for appealing and artistic satisfaction which is visibly functioning in some other cultures, and perhaps present in others; another for entertainment and for communication. In the song texts it employs, they communicate straight facts to those who comprehend the language in which it is understood.

If the songs of Khensay allow emotional expression, give aesthetic pleasure, entertain, and communicate, it is clear that they contribute to the connection and firmness of culture in the Bontok community. In this sense, possibly, they contribute no more or no less than any other aspect of culture, and we are possibly here using meaning and purpose in the limited sense of playing a part.

\section{REFERENCES}

[1] Bacwaden, Sofia O. 2006. Ayoweng. Bontoc, Mountain Province..

[2] 2004. Ayoweng (Tsinakhop).Bontoc, Mountain Province.

[3] Bakan, Michael B. 2012. World Music: Traditions and Transformations. 2nded. New York: McGraw-Hill.

[4] Blackmore, Susan. 1999. The Meme Machine. Oxford University Press.

[5] Brett, June Prill. 2015. Tradition and Transformation. Studies on Cordillera Indigenous Culture. Edited by D. Tolentino, Jr. Cordillera Studies Center.UP Baguio City.

[6] Connel, John and Chris Gibson. 2001. Soundtracks: Popular Identity, Music and Place. Routledge, New York.

[7] Drout, Michael D.C. “A Meme-Based Approach to Oral Tradition Theory.” Oral Tradition 21(2): 269-294.

[8] Fagsao, Jonnelle D. (2015) Kankanaey and Bontok Popular Contemporary Songs: Reflections of Igorot Social Conditions and Values. Unpublished Master's Thesis: MPSPC

[9] Finnegan, Ruth (1982) Oral Tradition and the Verbal Arts. A Guide to Research Practices. Routledge.London and New York

[10] Foley 1995 .The Singer of Tales in Performance. Bloomington: Indiana University Press.

[11] Foley 2002 .How to Read an Oral Poem. Urbana: University of Illinois Press. Ecompanion at http://www.oraltradition.org

[12] Garfias, Robert. 2004. Music: The Cultural Context. National Museum of Ethnology, Osaka

[13] Grant, G. 1990. Memetic Lexicon. http//pespmc1.vuc.ac.be/memes.html

[14] Hopper, Charles R. 1985. The Understanding of Music. University of Florida Wadsworth Publishing Company

[15] Kalof, L.1993. Dilemmas of Femininity. The Sociological Quarterly.

[16] Kemertelidze, Nino. 2003. Stylistic Repetition, Its Peculiarities and Types In Modern English. European Scientific Journal. 
[17] Merriam, Allan P. 1964. The Anthropology of Music. Northwestern University Press

[18] Nettl, Bruno. 1983. The Study of Ethnomusicology: Twenty-Nine Issues and Concepts. Urbana: U. of Illinois. 1983.

[19] Peck, M. S. 1978. The Road Less Travelled: A New Psychology of Love, Traditional Values, and Spiritual Growth. New York: Simon and Schuster.

[20] Saboy, Scott M. 2012. Voicing Ethnicity: Traditional Referentiality, The Ullalim, and Kalinga Ethnopop. The Cordillera Review.Journal of Philippine Culture and Society. Vol. 4, No. 2.Cordillera Studies Center, Univ. of the Phil. Baguio City.

[21] Schindler, Allan. 1980. Listening to Music. New York, Chicago, San Francisco, Dallas.

[22] Zelewicz, Lee F. E. 2006 .A Study of Ethnomusicology and the Influence of Western Cultural Ideas on the Realm of Native American Music Lycoming College 